\title{
Lymphopenia and DMTs for relapsing forms of MS
}

\section{Considerations for the treating neurologist}

\author{
Edward J. Fox, MD, PhD, Guy J. Buckle, MD, MPH, Barry Singer, MD, Vibhuti Singh, PhD, and Aaron Boster, MD \\ Neurology: Clinical Practice February 2019 vol. 9 no. 1 53-63 doi:10.1212/CPJ.0000000000000567
}

\author{
Correspondence \\ Dr. Boster \\ aaron.boster@ohiohealth.com
}

\section{Abstract}

\section{Purpose of review}

To provide neurologists with an update on the proposed mechanisms of action (MOAs) of disease-modifying therapies (DMTs) for the treatment of relapsing MS, and their effect on peripheral blood leukocytes, in order to inform treatment decisions.

\section{Recent findings}

DMTs have vastly differing MOAs, including effects on peripheral blood leukocyte counts, particularly lymphocytes. The clinical implications of changes in lymphocyte counts need to be understood in the context of the underlying MOAs of each respective DMT, with treatment tailored to individual patient needs.

\section{Summary}

DMTs can alter lymphocyte counts, subsets, activation, and distribution, and thus can influence immune surveillance. Serial monitoring of total leukocytes and absolute lymphocyte counts (ALCs) is advisable in patients receiving DMTs. ALCs should be interpreted regarding expected immunologic changes and individual patient characteristics. Any decision to switch DMTs should consider these factors, along with drug efficacy, safety, and effect on quality of life.

MS is a chronic, immune-mediated, demyelinating CNS disorder ${ }^{1}$ associated with development of neurologic deficits and subsequent accumulation of physical and cognitive disability. ${ }^{2}$ Around 2.3 million people worldwide and 400,000 in the USA have MS, ${ }^{3}$ with a higher incidence in women. ${ }^{4}$ Although there are regional variations, the prevalence of MS in the US in 2012 was 149.2 per 100,000 individuals. ${ }^{4}$ Relapsing forms of MS (RMS) account for over $80 \%$ of all MS cases at onset, and thus comprise a substantial proportion of MS cases under a neurologist's care. ${ }^{1}$

There is strong evidence indicating that infiltration of autoreactive immune cells into the CNS, particularly $\mathrm{CD} 4^{+}$and $\mathrm{CD} 8^{+} \mathrm{T}$ cells, plays an important role in MS pathogenesis. ${ }^{5}$ In addition,
MORE ONLINE

Infographic

NPub.org/NCP/023382

Multiple Sclerosis Clinic of Central Texas (EJF), Central Texas Neurology Consultants, Round Rock, TX; MS Institute at Shepherd Center (GJB), Atlanta, GA; The MS Center for Innovations in Care (BS), Missouri Baptist Medical Center, St Louis, MO; Indicia Medical Ltd. (VS), Part of the Fishawack Group of Companies, Hyderabad, India; and OhioHealth Multiple Sclerosis Center (AB), Riverside Methodist Hospital, Columbus, OH.

Funding information and disclosures are provided at the end of the article. Full disclosure form information provided by the authors is available with the full text of this article at Neurology.org/cp. 
a growing body of evidence has highlighted the involvement of B cells as important contributors to MS pathogenesis. ${ }^{5-8}$ The proposed mechanisms of action (MOAs) of various disease-modifying therapies (DMTs) for the treatment of patients with RMS generally involve some form of immunomodulation or lymphocyte depletion involving $\mathrm{T}$ cells, B cells, or both. DMTs target lymphocytes by modulating their activation, proliferation, or cytokine secretion, or by reducing their trafficking across the blood-brain barrier. ${ }^{5,8}$

As this review indicates, a nuanced approach is necessary for interpreting changes in complete blood counts observed in relation to DMTs. There is no single "normal" lymphocyte level for each individual DMT, and it is recommended that due consideration be given to expected changes vs changes that potentially signal unfavorable clinical outcomes. It is also worth noting that lymphopenia can occur in patients with MS that is unrelated to treatment with DMTs. ${ }^{9-11}$

\section{Proposed MOAs and evidence of lymphopenia for currently available DMTs}

Several injectable, oral, and infusible DMTs have been approved for the treatment of RMS, based on clinical trial evidence demonstrating reductions in MS relapse frequency, magnetic resonance imaging disease activity, and ongoing disability accumulation. Many of these DMTs result in a decrease in circulating $\mathrm{T}$ and $\mathrm{B}$ lymphocytes. However, it is important to note that circulating lymphocytes represent only a small proportion $(\sim 2 \%)$ of the total population; thus, they may not be an accurate indicator of the body's total lymphocyte pool and function. ${ }^{12,13}$ Furthermore, fluctuations in blood lymphocytes seldom correlate with changes in composition and number of lymphocyte subsets in other lymphoid and non-lymphoid organs. ${ }^{13}$ Therefore, blood lymphocytes provide limited information on an individual's immune status. ${ }^{13}$

A basic understanding of the underlying MOAs of DMTs and their effects on the immune system can help to inform the management of patients with RMS. The currently understood MOAs of DMTs and their known effects on lymphocyte subsets and the immune system are summarized in the table and figure, and discussed further in the following section of this review.

\section{Beta IFNs}

Numerous studies have demonstrated that anti-inflammatory properties of the beta interferons (IFNs) are mediated through downregulation of pro-inflammatory $\mathrm{CD}^{+}$and $\mathrm{CD} 8^{+}$memory $\mathrm{T}$ cells, memory B cells, and a concomitant increase in regulatory $\mathrm{T}$ cells (Tregs). ${ }^{14,15,18,51}$ Dose-related reductions in all cell lineages, predominantly leukocytes, have been observed with IFNs, with the most notable effect seen in total leukocyte and lymphocyte counts. ${ }^{14}$ It has been estimated that approximately two-thirds of patients treated with IFNs will develop cytopenia/lymphopenia, which generally resolves 34 months after treatment initiation. ${ }^{52}$

\section{Glatiramer acetate}

The synthetic polymer glatiramer acetate (GA) does not affect absolute lymphocyte counts (ALCs). ${ }^{53}$ Instead, GA appears to promote anti-inflammatory cytokine shifts in $\mathrm{CD} 4^{+}$and $\mathrm{CD}^{+} \mathrm{T}$ cells, restores Tregs, and decreases both memory $\mathrm{B}$ and $\mathrm{T}$ cells. ${ }^{20,54}$ Consequently, GA is infrequently associated with leukopenia, and when it does occur it is generally mild in nature. ${ }^{22,55}$

\section{Daclizumab}

Daclizumab binds to the alpha subunit (CD25) of the highaffinity interleukin-2 (IL-2) receptor expressed on activated $\mathrm{T}$ cells and modulates IL-2 signaling, resulting in an expansion of CD56 ${ }^{\text {BRIGHT }}$ natural killer (NK) cells and a reduction in proinflammatory activated $\mathrm{T}$ cells. ${ }^{25}$ In clinical trials, daclizumab was associated with reductions in total lymphocyte counts, and $\mathrm{T}$ and B cell counts of $\leq 10 \%$, which were reversible following treatment discontinuation, and a low overall incidence of lymphopenia. ${ }^{24-26}$

\section{Fingolimod}

Fingolimod affects lymphocyte migration to secondary lymphoid organs via down-modulation of sphingosine 1phosphate receptor 1 on lymphocytes, preventing egress of C-C chemokine receptor type $7+\left(\mathrm{CCR} 7^{+}\right)$lymphocytes, naïve and central memory $\mathrm{T}$ cells, and memory $\mathrm{B}$ cells, from lymph nodes. ${ }^{714}$ Fingolimod does not sequester effector T cells lacking CCR7 in lymph nodes. ${ }^{56}$ It has been shown that most patients who receive fingolimod can generate an immune response against both new and recalled antigens, and their lymphocyte functions remain largely intact. ${ }^{32}$

\section{Teriflunomide}

Teriflunomide, an immunomodulator, selectively and reversibly inhibits the mitochondrial enzyme dihydroorotate dehydrogenase and specifically targets proliferating lymphocytes (while sparing resting or slowly dividing cells), resulting in decreases in $\mathrm{CD}^{+}$and $\mathrm{CD} 8^{+} \mathrm{T}$ cells, memory B cells and NK cells. ${ }^{28}$ Overall, teriflunomide is associated with only infrequent mild lymphopenia and neutropenia, which tends to reverse with ongoing treatment or following treatment discontinuation. ${ }^{10}$

\section{Dimethyl fumarate}

The small molecule dimethyl fumarate (DMF) results in selective depletion of $\mathrm{CD}^{+}$over $\mathrm{CD} 4^{+} \mathrm{T}^{+}$cells. ${ }^{34}$ In clinical trials with DMF, a reduction in ALC of approximately $30 \%$ 


\section{Table Overview of the disease-modifying therapies in RMS}

\begin{tabular}{|c|c|c|c|c|c|c|c|}
\hline Treatment & $\begin{array}{l}\text { Patient-years of } \\
\text { drug exposure }\end{array}$ & $\begin{array}{l}\text { Proposed mechanism of } \\
\text { action }\end{array}$ & PK profile & $\begin{array}{l}\text { Effect on circulating } \\
\text { leukocytes }\end{array}$ & $\begin{array}{l}\text { Effect on immune } \\
\text { system/vaccine response }\end{array}$ & $\begin{array}{l}\text { Rate of recovery of } \\
\text { lymphocytes }\end{array}$ & $\begin{array}{l}\text { Rate of serious } \\
\text { infections }\end{array}$ \\
\hline \multirow[t]{5}{*}{$\begin{array}{l}\text { IFNs (Betaseron, Rebif, } \\
\text { Avonex, Extavia, Plegridy) }\end{array}$} & $\begin{array}{l}\text { Figures not readily } \\
\text { available-widely } \\
\text { used for over } 20 \\
\text { years }^{14}\end{array}$ & Recombinant cytokine $^{14}$ & & 1 month after treatment: & $\begin{array}{l}\text { Leukopenia } \\
\quad(\text { lymphopenia) }\end{array}$ & NA & NA \\
\hline & & $\begin{array}{l}\text { Downregulation of immune } \\
\text { recognition molecules such as } \\
\text { MHC Class II antigens, co- } \\
\text { stimulatory molecules and } \\
\text { adhesion molecules }{ }^{14}\end{array}$ & & $\begin{array}{l}\text { Considerable reduction vs } \\
\text { baseline in memory B cells }{ }^{15}\end{array}$ & $\begin{array}{l}\text { Normal humoral and } \\
\text { cellular response to } \\
\text { influenza vaccine }^{16,17}\end{array}$ & & \\
\hline & & $\begin{array}{l}\text { Promotes a TH1 (pro- } \\
\text { inflammatory)-TH2 (anti- } \\
\text { inflammatory) shift in cytokine } \\
\text { response }^{14}\end{array}$ & & $\begin{array}{l}\text { Decreases } \mathrm{CD} 4^{+} \text {and } \mathrm{CD} 8^{+} \mathrm{T} \text { cells } \\
\text { producing IFN-gamma and } \\
{\mathrm{IL}-4^{18}}\end{array}$ & & & \\
\hline & & $\begin{array}{l}\text { Reduction of lymphocyte } \\
\text { migration across the } \\
\text { blood-brain barrier }^{14}\end{array}$ & & & & & \\
\hline & & $\begin{array}{l}\text { Potential stimulation of neuronal } \\
\text { growth factor release }{ }^{14}\end{array}$ & & & & & \\
\hline \multirow[t]{3}{*}{$\begin{array}{l}\text { Glatiramer acetate } \\
\text { (Copaxone) }\end{array}$} & $>2,000,000^{19}$ & $\begin{array}{l}\text { Synthetic polymer that diminishes the } \\
\text { expression of MHC Class II } \\
\text { molecules, deactivates monocytes } \\
\text { and macrophages }^{14}\end{array}$ & $T_{\max }: 15-30 \min ^{20}$ & After 3 mo of treatment: ${ }^{21}$ & $\begin{array}{l}\text { Rare leukocytosis or } \\
\text { mild leukopenia }^{14}\end{array}$ & NA & $1 \%-2 \%^{22}$ \\
\hline & & $\begin{array}{l}\text { Promotes a TH1 (pro- } \\
\text { inflammatory)-TH2 (anti- } \\
\text { inflammatory) shift in cytokine } \\
\text { response }^{44}\end{array}$ & $\begin{array}{l}\text { Limited PK data in } \\
\text { patients with } \mathrm{MS}^{20}\end{array}$ & $\begin{array}{l}\text { Major increase in regulatory } \\
\mathrm{CD} 8^{+} \mathrm{T} \text { cells over baseline }\end{array}$ & 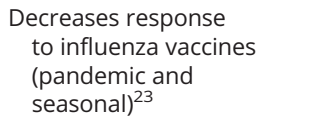 & & \\
\hline & & Exerts neuroprotective effects ${ }^{14}$ & & $\begin{array}{l}\text { Treatment activates the } \\
\text { transformation of conventional } \\
\mathrm{CD} 4^{+} \mathrm{CD} 25 \mathrm{~T} \text { cells to regulatory } \\
\mathrm{CD} 4^{+} \mathrm{CD} 25^{+} \mathrm{T} \text { cells } \mathrm{s}^{14}\end{array}$ & & & \\
\hline \multirow[t]{2}{*}{ Daclizumab (Zinbryta) } & $\begin{array}{l}5,214 \text { (clinical trials } \\
\text { only, data cutoff } \\
2016)^{24}\end{array}$ & $\begin{array}{l}\text { Humanized monoclonal } \\
\text { antibody }^{14}\end{array}$ & $\begin{array}{l}\text { Median } \\
\quad T_{\max }: 5-7 \text { days }^{25}\end{array}$ & $\begin{array}{l}\text { Increase in CD56 } 6^{\mathrm{BRIGHT}} \mathrm{NK} \text { cells } \\
\text { ( } 0.6 \% \text { of lymphocytes at } \\
\text { baseline to } 3.6 \% \text { at end of } \\
\text { treatment). Increase } \\
\text { apparent by week } 4^{26}\end{array}$ & $\begin{array}{l}\text { Potential lymphopenia } \\
\text { and leukopenia } \\
\text { (generally mild) }\end{array}$ & $\begin{array}{l}\text { 8-12 weeks after } \\
\text { discontinuation }{ }^{25}\end{array}$ & $3 \%$ vs 0 for placebo ${ }^{26}$ \\
\hline & & $\begin{array}{l}\text { CD25 antagonist that modulates IL-2 } \\
\text { signaling, leading to an expansion } \\
\text { of CD56 } \\
\text { thought } \mathrm{NK} \text { cells, which are } \\
\text { T cells that contribute pate to } \\
\text { inflammation in } \mathrm{MS}^{14,26}\end{array}$ & $\begin{array}{l}\text { Time to steady state: } \\
\text { 3-4 } \text { months }^{25}\end{array}$ & $\begin{array}{l}7 \%-10 \% \text { decrease in CD4 } 4^{+} \\
\text {and CD8 } 8^{+} \mathrm{T} \text {-cell counts } \\
\text { at week } 52^{26}\end{array}$ & & & \\
\hline
\end{tabular}


Table Overview of the disease-modifying therapies in RMS (continued)

\begin{tabular}{|c|c|c|c|c|c|c|c|}
\hline Treatment & $\begin{array}{l}\text { Patient-years of } \\
\text { drug exposure }\end{array}$ & $\begin{array}{l}\text { Proposed mechanism of } \\
\text { action }\end{array}$ & PK profile & $\begin{array}{l}\text { Effect on circulating } \\
\text { leukocytes }\end{array}$ & $\begin{array}{l}\text { Effect on immune } \\
\text { system/vaccine response }\end{array}$ & $\begin{array}{l}\text { Rate of recovery of } \\
\text { lymphocytes }\end{array}$ & $\begin{array}{l}\text { Rate of serious } \\
\text { infections }\end{array}$ \\
\hline & & & $T_{1 / 2}: 21 d^{25}$ & $\begin{array}{l}\mathrm{CD} 4^{+} / \mathrm{CD}^{+}{ }^{+} \text {ratio remained } \\
\text { constant }^{26}\end{array}$ & & & \\
\hline \multirow[t]{3}{*}{ Teriflunomide (Aubagio) } & $\begin{array}{l}\sim 162,000(\text { as of } \\
\text { October } 2017)^{27}\end{array}$ & $\begin{array}{l}\text { Active metabolite of } \\
\text { leflunomide }^{14}\end{array}$ & $\begin{array}{l}\text { Median } T_{\max }: 1-4 \\
\text { hours }^{10}\end{array}$ & $\begin{array}{l}\text { During first } 6 \text { weeks of } \\
\text { treatment: }^{10}\end{array}$ & $\begin{array}{l}\text { Potential mild } \\
\text { lymphopenia and } \\
\text { neutropenia }^{10,14}\end{array}$ & $\begin{array}{l}\text { May resolve with } \\
\text { ongoing } \\
\text { treatment or after } \\
\text { discontinuation }{ }^{10}\end{array}$ & $\begin{array}{l}1.4 \%(7 \mathrm{mg}) \text { and } 2.2 \% \\
(14 \mathrm{mg}) \text { vs } 2.1 \% \text { for } \\
\text { placebo }^{10}\end{array}$ \\
\hline & & $\begin{array}{l}\text { Pyrimidine synthesis inhibition } \\
\text { by inhibiting DHODH and } \\
\text { thereby reducing replication } \\
\text { of high-avidity } \\
\text { lymphocytes }^{14,28}\end{array}$ & $\begin{array}{l}\text { Time to steady state: } \\
\sim 3 \text { months }^{10}\end{array}$ & $\begin{array}{l}\text { 15\% mean decrease in WBCs, } \\
\text { mainly lymphocytes and } \\
\text { neutrophils }\end{array}$ & $\begin{array}{l}\text { Patients able to mount } \\
\text { a response to } \\
\text { neoantigen (rabies } \\
\text { vaccine); immune } \\
\text { response weaker vs } \\
\text { placebo-treated } \\
\text { patients }^{29}\end{array}$ & & \\
\hline & & & $\begin{array}{l}\mathrm{T}_{1 / 2} \sim 18 \text { and } 19 \text { days } \\
\text { for } 7 \text { and } 14 \mathrm{mg} \text {, } \\
\text { respectively }{ }^{10}\end{array}$ & & & & \\
\hline \multirow[t]{6}{*}{ Fingolimod (Gilenya) } & 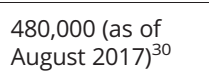 & $\begin{array}{l}\text { Sphingosine 1-phosphate } \\
\text { antagonist }^{7}\end{array}$ & $T_{\max }: 12-16 \mathrm{~h}^{9}$ & After 1 mo of treatment: ${ }^{31}$ & $\begin{array}{l}\text { Lymphocyte } \\
\text { redistribution }^{14}\end{array}$ & $\begin{array}{l}\text { 1-2 mo after } \\
\text { discontinuation }^{9}\end{array}$ & $\begin{array}{l}2.3 \% \text { vs } 1.6 \% \text { for } \\
\text { placebo }^{9}\end{array}$ \\
\hline & & $\begin{array}{l}\text { Redistribution of lymphocytes } \\
\text { in secondary lymphoid } \\
\text { tissue }^{7}\end{array}$ & $\begin{array}{l}\text { Time to steady state: } \\
\qquad 1-2 \mathrm{mo}^{9}\end{array}$ & $\begin{array}{l}\mathrm{CD}^{+} \mathrm{T} \text { cells decreased from } \\
78 \% \text { to } 39 \% \text { ( } 50 \% \text { overall } \\
\text { reduction from baseline) }\end{array}$ & $\begin{array}{l}\text { Immune responses } \\
\text { mounted to tetanus } \\
\text { and influenza }{ }^{32}\end{array}$ & & \\
\hline & & & $T_{1 / 2}: 6-9 d^{9}$ & $\begin{array}{l}\mathrm{CD}^{+} \mathrm{T} \text { cells decreased from } \\
59 \% \text { to } 12 \% \text { ( } 80 \% \text { overall } \\
\text { reduction from baseline) }\end{array}$ & $\begin{array}{l}\text { Reduced response } \\
\text { rates vs placebo- } \\
\text { treated patients }{ }^{32}\end{array}$ & & \\
\hline & & & & $\begin{array}{l}\mathrm{CD}^{\mathrm{C}} 9^{+} \mathrm{B} \text { cells decreased from } \\
8 \% \text { to } 3 \% \text { ( } 63 \% \text { overall } \\
\text { reduction from baseline) }\end{array}$ & & & \\
\hline & & & & $\begin{array}{l}\mathrm{CD}^{+} / \mathrm{CD}^{+}{ }^{+} \text {ratio decreased } \\
\text { from } 3.6 \text { to } 0.6 \text { ( } 83 \% \text { overall } \\
\text { reduction from baseline) }\end{array}$ & & & \\
\hline & & & & $\begin{array}{l}\text { NK cells increased from } 11 \% \text { to } \\
51 \% \text { ( } 364 \% \text { overall increase } \\
\text { from baseline) }\end{array}$ & & & \\
\hline $\begin{array}{l}\text { Dimethyl fumarate } \\
\text { (Tecfidera) }\end{array}$ & $\begin{array}{l}>464,000 \text { (as of } \\
\text { January } 2017)^{33}\end{array}$ & Fumaric acid methyl ester ${ }^{14}$ & $\begin{array}{l}\text { Median } T_{\max }: \\
2-2.5 \mathrm{~h}^{11}\end{array}$ & After 12 mo of treatment: ${ }^{34}$ & $\begin{array}{l}\text { Potential leukopenia } \\
\text { (lymphopenia) })^{11,14}\end{array}$ & $\begin{array}{l}4 \text { wk after } \\
\text { discontinuation in } \\
\text { clinical trials } \\
\text { (lower than }^{\text {baseline) }}{ }^{11}\end{array}$ & $\begin{array}{l}2.0 \% \text { vs } 2.0 \% \text { for } \\
\text { placebo }^{11}\end{array}$ \\
\hline
\end{tabular}




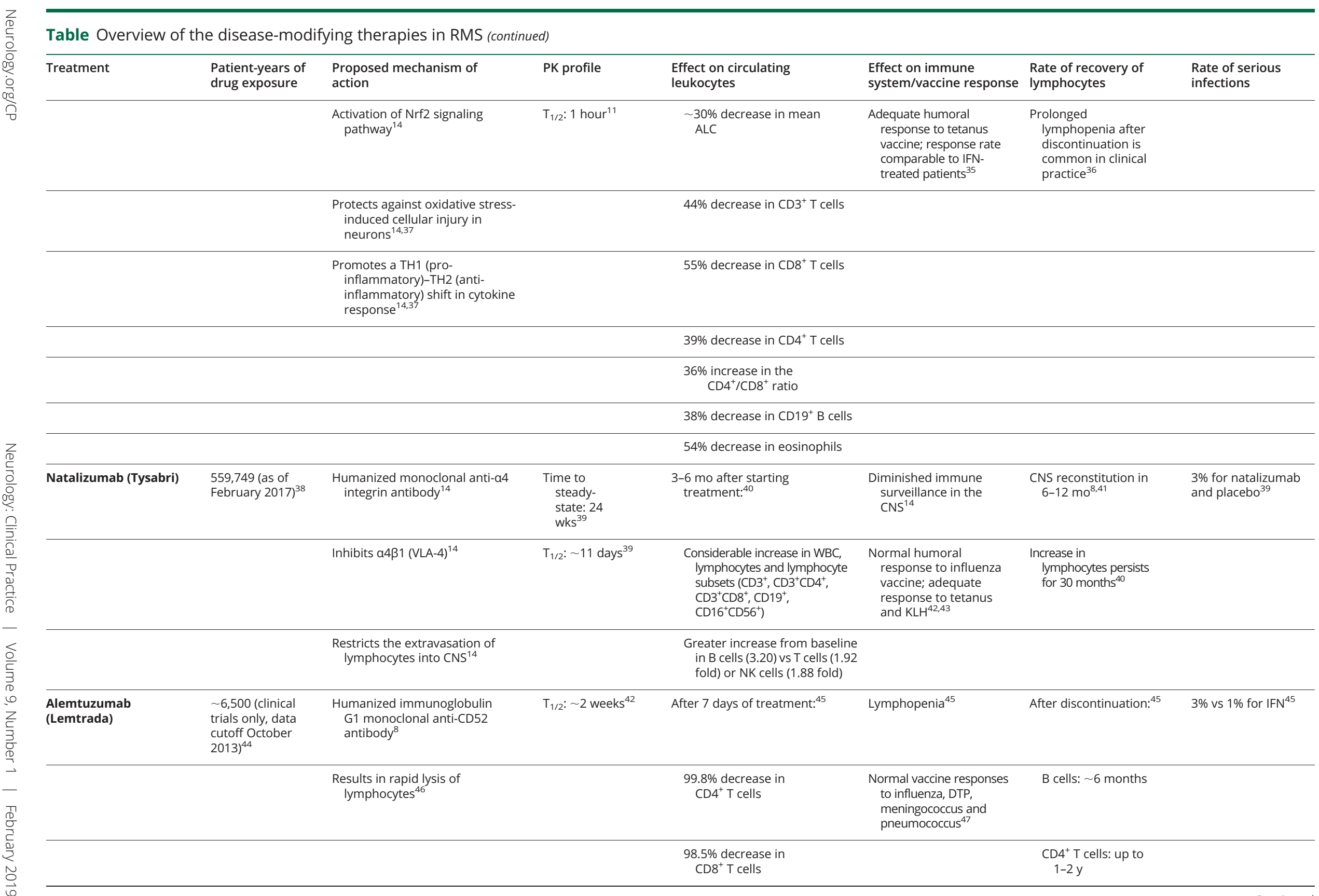


was observed in the first year of treatment. ${ }^{11}$ In addition, prolonged lymphopenia ( $\geq 6$ months) was seen in $2.2 \%$ of patients. ${ }^{57}$ One month after stopping treatment, mean counts increased, but did not return to baseline levels in all patients. $^{11}$

\section{Natalizumab}

Natalizumab, an anti- $\alpha 4$ integrin monoclonal antibody (mAb), affects lymphocyte migration to the CNS. Distinct from other $\mathrm{mAbs}$, it leads to considerable increases in $\mathrm{CD} 4^{+}$ and $\mathrm{CD} 8^{+} \mathrm{T}$ cells, $\mathrm{CD} 19^{+} \mathrm{B}$ cells, and NK cells, with no effect on the $\mathrm{CD} 4^{+} / \mathrm{CD}^{+} \mathrm{T}$-cell ratio in the periphery but a reduction in the CNS. ${ }^{40,41}$ The increases in ALC following natalizumab infusion likely occur as a result of increased release of $\mathrm{CD} 34^{+}$progenitor cells from bone marrow as well as impaired egress of lymphocytes from the periphery, with concomitant reduction in lymphocytes in the CSF and notable reduction in the $\mathrm{CSF} \mathrm{CD}^{+} / \mathrm{CD}^{+}$ratio. $^{39,58}$ After discontinuation, circulating lymphocytes usually return to baseline levels within 16 weeks; the $\mathrm{CD} 4^{+} / \mathrm{CD}^{+}$ratio normalizes within 6 months. ${ }^{8,39,41}$

\section{Alemtuzumab}

Alemtuzumab, an anti-CD52 mAb, causes near-complete depletion of circulating lymphocytes: dramatic drops in $\mathrm{CD}^{+}$and $\mathrm{CD} 8^{+} \mathrm{T}$ cells, $\mathrm{CD} 19^{+} \mathrm{B}$ cells, and NK cells have been observed after treatment, followed by variable reconstitution of leukocyte subpopulations, generally over 6-12 months. ${ }^{45,59}$ During alemtuzumab treatment, ALC decreases rapidly after the first infusion; however, all cell types, including memory $\mathrm{CD} 4^{+}$and $\mathrm{CD} 8^{+} \mathrm{T}$ cells, start to recover within the first month post-infusion, with a selective delay in $\mathrm{CD}^{+} \mathrm{T}$ cell reconstitution (taking $\leq 2$ years to normalize vs $\mathrm{CD}^{+} \mathrm{T}$ cells, which return to normal after 3 months of treatment). B cells are restored approximately 6 months post-discontinuation. ${ }^{8,45}$

\section{Ocrelizumab}

Ocrelizumab, an anti-CD20 mAb, leads to pronounced B-cell lymphopenia that has been shown to persist for a median of 72 weeks after last infusion. ${ }^{49}$ Following the first infusion, $\mathrm{B}$ cell counts are reduced within 2 weeks and remain depleted throughout ongoing treatment. B cells have been shown to recover to baseline levels/lower limit of normal 2.5 years after discontinuation in $90 \%$ of patients. ${ }^{49}$ 


\section{Clinical implications of lymphopenia}

DMTs alter normal immune responses and thus have the potential to increase infection risk. However, rates of serious infections reported in clinical trials are low (1\%-3\%) and similar between DMTs (table). Nevertheless, there are some important differences between DMTs with respect to the risk of some serious opportunistic infections, including progressive multifocal leukoencephalopathy (PML), a demyelinating disease associated with John Cunningham virus (JCV) infection. Ongoing clinical and postmarketing safety studies continue to collect information on infections in patients receiving DMTs.

\section{Serious opportunistic infections associated with DMTs}

Extensive experience with GA and IFNs has not elicited safety concerns with respect to opportunistic infections or PML; to date, neither teriflunomide, daclizumab, nor ocrelizumab has been associated with increased risk of opportunistic infections or PML in the RMS population. . $^{14,25,49,60}$ However, further long-term data are needed for ocrelizumab. ${ }^{61}$ Daclizumab was voluntarily withdrawn from the market following reports of inflammatory encephalitis and meningoencephalitis. ${ }^{62}$

Fingolimod has been associated with opportunistic infections including herpes viruses and cryptococcal infections. ${ }^{14}$ In clinical trials, 2 patients died of herpetic infections, and cases of fatal cryptococcal meningitis and disseminated cryptococcal infections have been reported in the postmarketing setting. The overall risk of PML not attributed to prior natalizumab treatment remains very rare, and is estimated to be $\sim 1: 12,000$ patients. As of August 2017, 15 fingolimod-treated patients were reported to have developed PML in the absence of natalizumab treatment in the preceding 6 months. ${ }^{30}$ However, these cases of PML were not associated with sustained grade 4 (ALC $<0.2 \times 10^{9} / \mathrm{L}$ ) lymphopenia. ${ }^{9,30,61}$ An additional 4 cases of PML were later reported. ${ }^{63}$

DMF-associated lymphopenia and PML have been a recent area of focus; $\mathrm{CD} 8^{+} \mathrm{T}$ lymphocytes, which are likely critical to defend against JCV, ${ }^{64}$ are selectively depleted by DMF, and their sustained reduction may result in an increased risk of developing PML. ${ }^{34}$ To date, one case of PML in a patient with prolonged lymphopenia has been reported in a clinical trial, ${ }^{11}$ and 4 cases have been reported in the postmarketing setting in the presence of lymphopenia $\left(<0.8 \times 10^{9} / \mathrm{L}\right)$ persisting for $>6$ months. ${ }^{11,61}$

Natalizumab prescribing information indicates a general increased risk of developing infections, ${ }^{39}$ and the risk of PML is known to be higher for natalizumab (approximately 4 in 1,000 patients) than other DMTs, increasing with treatment duration ( $>24$ months), prior immunosuppressant exposure, JCV antibody positivity, and older age ( $>44$ years). ${ }^{39,61,65}$ As of February 2017, there have been 711 cases of PML reported in patients with MS exposed to natalizumab, with a mortality rate $>20 \% .^{38}$ The mechanisms underlying PML development in natalizumab-treated patients remain unclear; it is assumed that impaired immunosurveillance in the CNS and mobilization of premature B cells infected by JCV into the CNS may be involved. ${ }^{61}$

Although no cases of PML following alemtuzumab treatment have been reported in patients with MS, several cases of Listeria-associated infections during or soon after an

Figure Simple schematic depicting the general effects of selected DMTs on lymphocytes
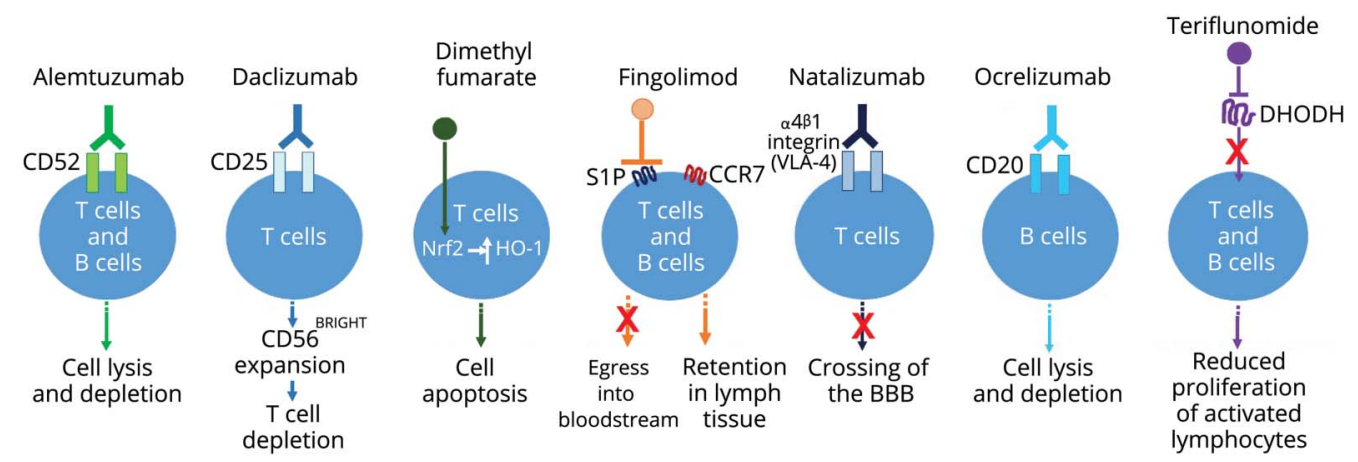

The mechanisms of action of each DMT have not been fully elucidated in relapsing MS; the depiction shown in this schematic with respect to effects on lymphocytes is based on currently available evidence. Alemtuzumab is a humanized immunoglobulin-1 monoclonal anti-CD52 antibody that results in rapid lysis of lymphocytes. ${ }^{42}$ Daclizumab is a humanized monoclonal anti-CD25 antibody that leads to CD56 ${ }^{\text {BRIGHT }}$ expansion via interleukin-2 modulation, and consequently, to activated T-cell depletion. ${ }^{14}$ Dimethyl fumarate is believed to exert its lymphopenic effect through activation of the Nrf2 pathway, which leads to induction of the anti-inflammatory stress protein $\mathrm{HO}-1$ and consequently apoptosis of primarily CD8 ${ }^{+} \mathrm{T}_{\text {cells. }}{ }^{8,34}$ Fingolimod is a sphingosine 1 phosphate (S1P) agonist; after binding to and activating S1P1, fingolimod acts as a functional antagonist and prevents CCR7 ${ }^{+}$lymphocytes, including naive and central memory T cells and B cells, from exiting lymph nodes. ${ }^{7,8}$ Natalizumab is a humanized monoclonal anti-a4 integrin antibody that binds a4 31 integrin (very late antigen-4 [VLA-4]) and prevents lymphocytes from crossing the blood-brain barrier (BBB) and entering the CNS. ${ }^{14}$ Ocrelizumab is a recombinant humanized monoclonal antibody directed against CD20-expressing B-cells; it results in antibody-dependent cellular cytolysis following cell surface binding to B lymphocytes. ${ }^{49}$ Teriflunomide inhibits de novo pyrimidine synthesis in rapidly dividing cells by inhibiting the enzyme dihydroorotate dehydrogenase $(\mathrm{DHODH})$, causing a cytostatic effect on activated/proliferating T and B cells. ${ }^{14}$ 
alemtuzumab treatment cycle have emerged in the postmarketing setting. ${ }^{14}$ In clinical trials with alemtuzumab, antiviral prophylaxis reduced the frequency of herpes simplex infections.

Together, these studies provide evidence that, for the majority of currently available DMTs, there is no obvious link between ALC and overall risk of opportunistic infections. Nevertheless, continuous assessment of infection risk before, during, and after administering DMTs is advisable and has profound clinical relevance given the link between MS exacerbations and infection. ${ }^{66}$ To minimize infection risk, a comprehensive analysis of patient characteristics is required for deciding on the optimal DMT, including any history of infectious disorders, prior exposure to immunosuppressants, age, and immune status. For example, patients with low baseline lymphocyte counts and women with low body mass index may be at particular risk of developing clinically significant lymphopenia with fingolimod. ${ }^{67}$ In patients receiving natalizumab, prior immunosuppressant use has also been associated with increased risk of PML, ${ }^{68}$ and the recent American Academy of Neurology (AAN) practice guidelines on DMTs in MS state that a discussion regarding switching to a DMT with a lower risk of PML should take place for patients who are or become JCV antibody-positive while receiving natalizumab. ${ }^{69}$ It is important that healthcare providers look beyond lymphocyte count and remain vigilant to detect clinical signs and symptoms in order to act swiftly in cases of opportunistic infection.

\section{Lymphopenia and relationship with DMT efficacy}

Because lymphocytes appear to be important contributors to MS pathology, elucidating the significance of DMTinduced lymphopenia and predicting which patients are at risk of serious or opportunistic infections, and who might benefit most from certain treatments, are important for clinical decision-making. Based on currently available data, there does not appear to be a link between lymphopenia and DMT efficacy, although such a link cannot be excluded given the complex mechanisms involved. Despite longstanding clinical experience with IFN-beta, immunologic markers that predict treatment efficacy have not been identified. ${ }^{51}$ Similarly, lymphopenia associated with DMF treatment was not predictive of good clinical response or breakthrough MS activity, ${ }^{36}$ and no association between the degree of lymphopenia and clinical outcomes was observed in patients treated with fingolimod. ${ }^{70}$ Additionally, earlier evidence of IL-21 and differential lymphocyte reconstitution as potential biomarkers for relapse risk after alemtuzumab treatment has not been validated. ${ }^{71}$

Advances are being made towards establishing clinically relevant markers of treatment response in RMS, with neurofilaments representing a particular focus. ${ }^{72}$ However, in the absence of reliable biomarkers, close patient monitoring
With the exception of prolonged lymphopenia with DMF, lymphopenia alone is not a signal to switch treatments or reduce dosage in the majority of cases.

and comprehensive patient education are of paramount importance.

\section{Alternative dosing strategies to address lymphopenia}

With the exception of prolonged lymphopenia with DMF, lymphopenia alone is not a signal to switch treatments or reduce dosage in the majority of cases. Rather, lymphopenia may be an expected consequence of the MOA of several DMTs and does not necessarily signify clinically significant loss of immunity. Nevertheless, some physicians have devised alternative dosing strategies to reduce lymphopenia risk. A recent observational study reported that fingolimod-associated lymphopenia could be mitigated by utilizing an every-other-day dosing regimen; however, there was a considerable increase in risk of relapse or new magnetic resonance imaging lesions. Furthermore, it is also currently unknown whether alternate-day dosing has any additional effect on overall safety outcomes. ${ }^{73}$

\section{Switching DMTs}

Suspending or switching between DMTs may become necessary when patients fail to respond to therapy or when concerns emerge about actual/potential adverse events (such as opportunistic or recurrent infections, hepatotoxicity, renal insufficiency, and cardiovascular diseases-see individual product labels). When switching between therapies, it is important to consider both MOA and duration of action (table) of each therapy and understand the risks and benefits associated with each. To avoid inadvertent additive treatment effects, ALC monitoring and an optimal washout period should be elucidated for each drug-switching combination: a long washout period may cause disease rebound, and a shorter period may be associated with safety issues due to the synergetic effect of more than one drug on the immune system. ${ }^{74}$ No evidence-based guidelines for recommended washout periods between DMTs currently exist, and clinical practice varies widely. The recent AAN practice guidelines on DMTs in MS make no recommendations for switching in cases of lymphopenia. ${ }^{69}$ As each treating physician has their own approach to patient management, such as low lymphocyte counts that would prompt discontinuation, switching DMTs due to lymphopenia is more likely to be based on personal protocols rather than set guidelines. Monitoring of normalization of lymphocyte counts after DMT switches may help guide sequence timing. 
The presence of lymphopenia following initiation of DMTs known to cause cell lysis or redistribution is not usually sufficient to warrant switching drugs or reducing dosage. However, per the DMF prescribing information, interruption of treatment should be considered in patients with lymphocyte counts less than $0.5 \times 10^{9} / \mathrm{L}$ persisting for more than 6 months. Although fingolimod treatment was interrupted in patients with ALCs $<0.2 \times 10^{9} / \mathrm{L}$ in the pivotal clinical trials, ${ }^{75-77}$ post-marketing safety analysis and further studies have not shown a clear correlation between the degree of lymphopenia and opportunistic infections. ${ }^{78}$ The prescribing information contains no language regarding the necessity for discontinuation of fingolimod for lymphopenia; however, due to treatment interruptions in the pivotal clinical trials, information on patients with ALCs $<0.2 \times 10^{9} / \mathrm{L}$ who continued fingolimod therapy is limited.

To conclude, a nuanced approach is proposed, where the underlying MOA of the DMT and key patient characteristics are considered. There might not be a "normal"lymphocyte count for patients with RMS on DMTs; the implications of any changes in lymphocyte count need to be understood in the context of the underlying MOA of prescribed DMTs, and treatment tailored to individual patient needs.

\section{Author contributions}

E.J. Fox: drafting/revising the manuscript. G. Buckle: drafting/revising the manuscript; study concept or design; analysis or interpretation of data. B. Singer: drafting/ revising the manuscript, data acquisition, study concept or design, analysis or interpretation of data. V. Singh: drafting/ revising the manuscript. A. Boster: drafting/revising the manuscript.

\section{Study funding}

Medical writing and editorial assistance in the development of this manuscript were provided by Vibhuti Singh, $\mathrm{PhD}$, at Indicia Medical Ltd., part of the Fishawack Group of Companies. This service was supported by Novartis Pharmaceuticals Corporation, East Hanover, NJ.

\section{Disclosure}

E.J. Fox serves on scientific advisory boards for Acorda, Bayer, Biogen, EMD Serono, Genentech Roche, Novartis, Sanofi Genzyme, and Teva; has received funding for travel and/or speaker honoraria from Acorda, Biogen, EMD Serono, Genentech Roche, Novartis, Sanofi Genzyme, and Teva; serves as a consultant for Bayer, Biogen, EMD Serono, Genentech Roche, Novartis, Sanofi Genzyme, and Teva Neuroscience; serves on speakers' bureaus for Acorda, Biogen, EMD Serono, Genetech Roche, Novartis, Sanofi Genzyme, and Teva; receives research support from AbbVie, Allergan, Biogen, Celgene, Chugai, EMD Serono, Genentech Roche, Mallinckrodt, MedDay, Novartis, Sanofi Genzyme, Teva Neuroscience, TG Therapeutics, and National Multiple Sclerosis Society; and has participated in medico-legal cases. G.J. Buckle has received funding for travel and/or speaker honoraria from Biogen-Idec, Celgene, EMD-Serono, Genentech, Genzyme- Sanofi, Novartis, and Teva; serves as a consultant for Biogen-Idec, Celgene, EMDSerono, Genentech, Genzyme- Sanofi, Novartis, and Teva; and serves on speakers' bureaus for Biogen-Idec, EMDSerono, Genentech, Genzyme-Sanofi, Novartis, and Teva. B. Singer has received funding for travel and/or speaker honoraria from Acorda, Bayer, Biogen, EMD Serono, Genentech, Roche, Novartis, Sanofi Genzyme, and Teva; serves as a consultant for Bayer, Biogen, EMD Serono, Genentech, Novartis, Sanofi Genzyme, and Teva; serves on speakers' bureaus for Acorda, Bayer, Biogen, EMD Serono, Genentech, Novartis, Sanofi Genzyme, and Teva; and receives research support from Acorda, Alkermes, Biogen, MedImmune, Novartis, Roche, and Sanofi Genzyme. V. Singh is an employee of Fishawack Group of Companies, whose services were paid for by Novartis. A. Boster serves as a consultant for Genzyme, Genentech, and Biogen; serves on speakers' bureaus for Genzyme, Genentech, Biogen, and Novartis; and has received honoraria or research support from Acorda Therapeutics, Actelion Pharmaceuticals, CNS Therapeutics, Jazz Pharmaceuticals, Medtronic, Roche, Serono, Questcor Pharmaceuticals, and Teva Pharmaceuticals. Full disclosure form information provided by the authors is available with the full text of this article at Neurology.org/cp.

\section{TAKE-HOME POINTS}

$\rightarrow$ On the basis of the proposed MOAs of many of the DMTs used in the treatment of RMS, lymphopenia is an anticipated side effect. However, not all patients experience lymphopenia, and its severity may vary between individuals.

$\rightarrow$ Lymphopenia is usually reversible after discontinuation of most DMTs, with infrequent exceptions. However, the length of time for complete reversal of lymphopenia varies between individuals and depends greatly on the specific DMT.

$\rightarrow$ Despite differences in MOAs of the various DMTs, overall rates of serious infection appear to be low, as reported in clinical trials.

$\rightarrow$ There is currently no direct evidence to suggest that DMT efficacy, in terms of either clinical response or breakthrough MS activity, is related to the presence or severity of lymphopenia.

$\rightarrow$ The presence of lymphopenia following initiation of DMTs known to cause cell lysis or redistribution is not usually sufficient to warrant switching drugs or reducing dosage. 


\section{Publication history}

Received by Neurology: Clinical Practice October 6, 2017. Accepted in final form September 20, 2018.

\section{References}

1. Noseworthy JH, Lucchinetti C, Rodriguez M, Weinshenker BG. Multiple sclerosis. N Engl J Med 2000;343:938-952.

2. Tsang BK, Macdonell R. Multiple sclerosis- diagnosis, management and prognosis. Aust Fam Physician 2011;40:948-955.

3. Global Burden of Disease Study C. Global, regional, and national incidence, prevalence, and years lived with disability for 301 acute and chronic diseases and injuries in 188 countries, 1990-2013: a systematic analysis for the Global Burden of Disease Study 2013. Lancet 2015;386:743-800.

4. Dilokthornsakul P, Valuck RJ, Nair KV, Corboy JR, Allen RR, Campbell JD. Multiple sclerosis prevalence in the United States commercially insured population. Neurology 2016;86:1014-1021.

5. Farjam M, Zhang GX, Ciric B, Rostami A. Emerging immunopharmacological targets in multiple sclerosis. J Neurol Sci 2015;358:22-30.

6. Blauth K, Owens GP, Bennett JL. The ins and outs of B cells in multiple sclerosis. Front Immunol 2015;6:565.

7. Blumenfeld S, Staun-Ram E, Miller A. Fingolimod therapy modulates circulating B cell composition, increases B regulatory subsets and production of IL-10 and TGFbeta in patients with multiple sclerosis. J Autoimmun 2016;70: $40-51$.

8. Bruck W, Gold R, Lund BT, et al. Therapeutic decisions in multiple sclerosis: moving beyond efficacy. JAMA Neurol 2013;70:1315-1324.

9. GILENYA ${ }^{\circ}$ (Fingolimod). Prescribing Information; 2016.

10. AUBAGIO $^{\otimes}$ (Teriflunomide). Prescribing Information; 2016

11. TECFIDERA ${ }^{\oplus}$ (Dimethyl fumarate). Prescribing Information; 2016

12. Trepel F. Number and distribution of lymphocytes in man: a critical analysis. Klin Wochenschr 1974;52:511-515.

13. Westermann J, Pabst R. Lymphocyte subsets in the blood: a diagnostic window on the lymphoid system? Immunol Today 1990;11:406-410.

14. Winkelmann A, Loebermann M, Reisinger EC, Hartung HP, Zettl UK. Diseasemodifying therapies and infectious risks in multiple sclerosis. Nat Rev Neurol 2016; 12:217-233.

15. Baker D, Marta M, Pryce G, Giovannoni G, Schmierer K. Memory B cells are major targets for effective immunotherapy in relapsing multiple sclerosis. EBioMedicine 2017;16:41-50.

16. Mehling M, Fritz S, Hafner P, et al. Preserved antigen-specific immune response in patients with multiple sclerosis responding to IFNbeta-therapy. PLoS One 2013;8: e78532.

17. Schwid SR, Decker MD, Lopez-Bresnahan M. Rebif-Influenza Vaccine Study Investigators. Immune response to influenza vaccine is maintained in patients with multiple sclerosis receiving interferon beta-1a. Neurology 2005;65:1964-1966.

18. Furlan R, Bergami A, Lang R, et al. Interferon-beta treatment in multiple sclerosis patients decreases the number of circulating $T$ cells producing interferon-gamma and interleukin-4. J Neuroimmunol 2000;111:86-92.

19. Boster AL, Ford CC, Neudorfer O, Gilgun-Sherki Y. Glatiramer acetate: long-term safety and efficacy in relapsing-remitting multiple sclerosis. Expert Rev Neurother 2015; 15:575-586

20. Messina S, Patti F. The pharmacokinetics of glatiramer acetate for multiple sclerosis treatment. Expert Opin Drug Metab Toxicol 2013;9:1349-1359.

21. Karandikar NJ, Crawford MP, Yan X, et al. Glatiramer acetate (Copaxone) therapy induces $\mathrm{CD} 8(+) \mathrm{T}$ cell responses in patients with multiple sclerosis. J Clin Invest 2002;109:641-649.

22. Winkelmann A, Loebermann M, Reisinger EC, Zettl UK. Multiple sclerosis treatment and infectious issues: update 2013. Clin Exp Immunol 2014;175:425-438.

23. Olberg HK, Cox RJ, Nostbakken JK, Aarseth JH, Vedeler CA, Myhr KM. Immunotherapies influence the influenza vaccination response in multiple sclerosis patients: an explorative study. Mult Scler 2014;20:1074-1080.

24. Giovannoni G, Kappos L, Gold R, et al. Safety and tolerability profile of daclizumab in patients with relapsing-remitting multiple sclerosis: an integrated analysis of clinical studies. Mult Scler Relat Disord 2016;9:36-46.

25. ZINBRYTA (Daclizumab). Prescribing Information; 2016

26. Gold R, Giovannoni G, Selmaj K, et al. Daclizumab high-yield process in relapsingremitting multiple sclerosis (SELECT): a randomised, double-blind, placebocontrolled trial. Lancet 2013;381:2167-2175.

27. Lebrun-Frénay C, Rog D, Benamor M, Jurgensen S, Truffinet P, Ghezzi A. Teriflunomide (Aubagio ${ }^{\circledast}$ ) international pregnancy registry: enrollment update. Presented at the 7th Joint ECTRIMS-ACTRIMS Meeting, October 25-28 2017, Paris, France: Poster EP1732.

28. Bar-Or A, Pachner A, Menguy-Vacheron F, Kaplan J, Wiendl H. Teriflunomide and its mechanism of action in multiple sclerosis. Drugs 2014;74:659-674.

29. Bar-Or A, Wiendl H, Miller B, et al. Randomized study of teriflunomide effects on immune responses to neoantigen and recall antigens. Neurol Neuroimmunol Neuroinflamm 2015;2:e70.

30. Berger JR, Cree BA, Greenberg B, et al. Progressive multifocal leukoencephalopathy after fingolimod treatment. Neurology 2018;90:e1815-e1821.

31. Rudnicka J, Czerwiec M, Grywalska E, et al. Influence of fingolimod on basic lymphocyte subsets frequencies in the peripheral blood of multiple sclerosis patients - preliminary study. Cent Eur J Immunol 2015;40:354-359.

32. Kappos L, Mehling M, Arroyo R, et al. Randomized trial of vaccination in fingolimodtreated patients with multiple sclerosis. Neurology 2015;84:872-879.

33. Cohan SL, Moses H, Calkwood J, et al. Clinical outcomes in patients with relapsingremitting multiple sclerosis who switch from natalizumab to delayed-release dimethyl fumarate: a multicenter retrospective observational study (STRATEGY). Mult Scler Relat Disord 2018;22:27-34.

34. Spencer CM, Crabtree-Hartman EC, Lehmann-Horn K, Cree BA, Zamvil SS. Reduction of CD8(+) T lymphocytes in multiple sclerosis patients treated with dimethyl fumarate. Neurol Neuroimmunol Neuroinflamm 2015;2:e76.

35. von Hehn C, Howard L, Liu S, Meka V, Pultz P, Sheikh S. A randomized, open label study to assess the immune response to vaccination in patients with relapsing forms of multiple sclerosis treated with delayedrelease dimethyl fumarate compared to nonpegylated interferon. Presented at the 7th Joint ECTRIMS-ACTRIMS Meeting, October 25-28 2017, Paris, France: Poster LB04.

36. Longbrake EE, Naismith RT, Parks BJ, Wu GF, Cross AH. Dimethyl fumarateassociated lymphopenia: risk factors and clinical significance. Mult Scler J Exp Transl Clin 2015;1:1-8.

37. Bomprezzi R. Dimethyl fumarate in the treatment of relapsing-remitting multiple sclerosis: an overview. Ther Adv Neurol Disord 2015;8:20-30.

38. Singer BA. The role of natalizumab in the treatment of multiple sclerosis: benefits and risks. Ther Adv Neurol Disord 2017;10:327-336.

39. TYSABRI ${ }^{\circledast}$ (Natalizumab). Prescribing Information; 2016

40. Koudriavtseva T, Sbardella E, Trento E, Bordignon V, D’Agosto G, Cordiali-Fei P. Long-term follow-up of peripheral lymphocyte subsets in a cohort of multiple sclerosis patients treated with natalizumab. Clin Exp Immunol 2014;176: 320-326

41. Stuve O, Marra CM, Bar-Or A, et al. Altered CD4+/CD8+ T-cell ratios in cerebrospinal fluid of natalizumab-treated patients with multiple sclerosis. Arch Neurol 2006; 63:1383-1387.

42. Kaufman M, Pardo G, Rossman H, Sweetser MT, Forrestal F, Duda P. Natalizumab treatment shows no clinically meaningful effects on immunization responses in patients with relapsing-remitting multiple sclerosis. J Neurol Sci 2014; 341:22-27.

43. Vagberg M, Kumlin U, Svenningsson A. Humoral immune response to influenza vaccine in natalizumab-treated MS patients. Neurol Res 2012;34:730-733.

44. Ziemssen T, De Stefano N, Pia Sormani M, Van Wijmeersch B, Wiendl H, Kieseier BC. Optimizing therapy early in multiple sclerosis: an evidence-based view. Mult Scler Relat Disord 2015;4:460-469.

45. Zhang $\mathrm{X}$, Tao $\mathrm{Y}$, Chopra $\mathrm{M}$, et al. Differential reconstitution of $\mathrm{T}$ cell subsets following immunodepleting treatment with alemtuzumab (anti-CD52 monoclonal antibody) in patients with relapsing-remitting multiple sclerosis. J Immunol 2013; 191:5867-5874

46. LEMTRADA (Alemtuzumab). Prescribing Information; 2014.

47. McCarthy CL, Tuohy O, Compston DA, Kumararatne DS, Coles AJ, Jones JL. Immune competence after alemtuzumab treatment of multiple sclerosis. Neurology 2013;81:872-876

48. Hauser SL, Bar-Or A, Comi G, et al. Ocrelizumab versus interferon beta-1a in relapsing multiple sclerosis. N Engl J Med 2017;376:221-234.

49. OCREVUS ${ }^{\mathrm{TM}}$ (Ocrelizumab). Prescribing Information; 2017.

50. Hartung HP, Arnold DL, Bar-Or A, et al. Infections and serious infections with ocrelizumab in relapsing multiple sclerosis and primary progressive multiple sclerosis. Mult Scler J 2016;22:65876

51. Zafranskaya M, Oschmann P, Engel R, et al. Interferon-beta therapy reduces CD4+ and CD8+ T-cell reactivity in multiple sclerosis. Immunology 2007;121:29-39.

52. Rieckmann P, O'Connor P, Francis GS, Wetherill G, Alteri E. Haematological effects of interferon-beta-1a (Rebif) therapy in multiple sclerosis. Drug Saf 2004;27: $745-756$.

53. Lim ZW, Elwood E, Naveed H, Galea I. Lymphopenia in treatment-naive relapsing multiple sclerosis. Neurol Neuroimmunol Neuroinflamm 2016;3:e275.

54. Ireland SJ, Guzman AA, O'Brien DE, et al. The effect of glatiramer acetate therapy on functional properties of $B$ cells from patients with relapsing-remitting multiple sclerosis. JAMA Neurol 2014;71:1421-1428.

55. COPAXONE ${ }^{\otimes}$ (Glatiramer Acetate Injection). Prescribing Information; 2016

56. Brinkmann V, Davis MD, Heise CE, et al. The immune modulator FTY720 targets sphingosine 1-phosphate receptors. J Biol Chem 2002;277:21453-21457.

57. Fox RJ, Chan A, Gold R, et al. Characterizing absolute lymphocyte count profiles in dimethyl fumarate-treated patients with MS: patient management considerations. Neurol Clin Pract 2016;6:220-229.

58. Zohren F, Toutzaris D, Klarner V, Hartung HP, Kieseier B, Haas R. The monoclona anti-VLA-4 antibody natalizumab mobilizes CD34+ hematopoietic progenitor cells in humans. Blood 2008;111:3893-3895

59. Thomas K, Eisele J, Rodriguez-Leal FA, Hainke U, Ziemssen T. Acute effects of alemtuzumab infusion in patients with active relapsing-remitting MS. Neurol Neuroimmunol Neuroinflamm 2016;3:e228.

60. AUBAGIO $^{\circledR}$ (Teriflunomide). Summary of Product Characteristics; 2015

61. Berger JR. Classifying PML risk with disease modifying therapies. Mult Scler Relat Disord 2017;12:59-63.

62. Biogen AbbVie Press Release. March 2, 2018 [online]. Available at: businesswire com/news/home/20180302005168/en/Biogen\%C2\%A0and-AbbVie-Announce\% C2\%A0the-Voluntary\%C2\%A0Worldwide-Withdrawal-Marketing-Authorizations. Accessed March 29, 2018.

63. Mills EA, Mao-Draayer Y. Aging and lymphocyte changes by immunomodulatory therapies impact PML risk in multiple sclerosis patients. Mult Scler 2018;24: 1014-1022.

64. Du Pasquier RA, Kuroda MJ, Zheng Y, Jean-Jacques J, Letvin NL, Koralnik IJ. A prospective study demonstrates an association between JC virus-specific cytotoxic $\mathrm{T}$ lymphocytes and the early control of progressive multifocal leukoencephalopathy. Brain 2004;127:1970-1978.

65. Ho PR, Koendgen H, Campbell N, Haddock B, Richman S, Chang I. Risk of natalizumab-associated progressive multifocal leukoencephalopathy in patients with multiple sclerosis: a retrospective analysis of data from four clinical studies. Lancet Neurol 2017;16:925-933. 
66. Buljevac D, Flach HZ, Hop WC, et al. Prospective study on the relationship between infections and multiple sclerosis exacerbations. Brain 2002;125:952-960.

67. Warnke C, Dehmel T, Ramanujam R, et al. Initial lymphocyte count and low BMI may affect fingolimod-induced lymphopenia. Neurology 2014;83:2153-2157.

68. Bloomgren G, Richman S, Hotermans C, et al. Risk of natalizumab-associated progressive multifocal leukoencephalopathy. N Engl J Med 2012;366:1870-1880.

69. Rae-Grant A, Day GS, Marrie RA, et al. Practice guideline recommendations summary: disease-modifying therapies for adults with multiple sclerosis: report of the guideline development, dissemination, and implementation subcommittee of the American Academy of Neurology. Neurology 2018;90:777-788.

70. Fragoso YD, Spelman T, Boz C, et al. Lymphocyte count in peripheral blood is not associated with the level of clinical response to treatment with fingolimod. Mult Scler Relat Disord 2018;19:105-108.

71. Ruck T, Bittner S, Wiendl H, Meuth SG. Alemtuzumab in multiple sclerosis: mechanism of action and beyond. Int J Mol Sci 2015;16:16414-16439.

72. Bodini B, Calabresi PA. From neurofilament research to multiple sclerosis clinical practice: where do we stand? Neurology 2017;88:816-817.
73. Zecca C, Merlini A, Disanto G, et al. Half-dose fingolimod for treating relapsingremitting multiple sclerosis: observational study. Mult Scler 2018;24:167-174.

74. Klotz L, Grutzke B, Eveslage M, et al. Assessment of immune functions and MRI disease activity in relapsing-remitting multiple sclerosis patients switching from natalizumab to fingolimod (ToFingo-Successor). BMC Neurol 2015;15: 96.

75. Kappos L, Radue EW, O'Connor P, et al. A placebo-controlled trial of oral fingolimod in relapsing multiple sclerosis. N Engl J Med 2010;362:387-401.

76. Calabresi PA, Radue EW, Goodin D. Safety and efficacy of fingolimod in patients with relapsing-remitting multiple sclerosis (FREEDOMS II): a doubleblind, randomised, placebo-controlled, phase 3 trial. Lancet Neurol 2014;13: 545-556.

77. Cohen JA, Barkhof F, Comi G, et al. Oral fingolimod or intramuscular interferon for relapsing multiple sclerosis. N Engl J Med 2010;362:402-415.

78. Francis G, Kappos L, O'Connor P, et al. Temporal profile of lymphocyte counts and relationship with infections with fingolimod therapy. Mult Scler J 2014;20: $471-480$.

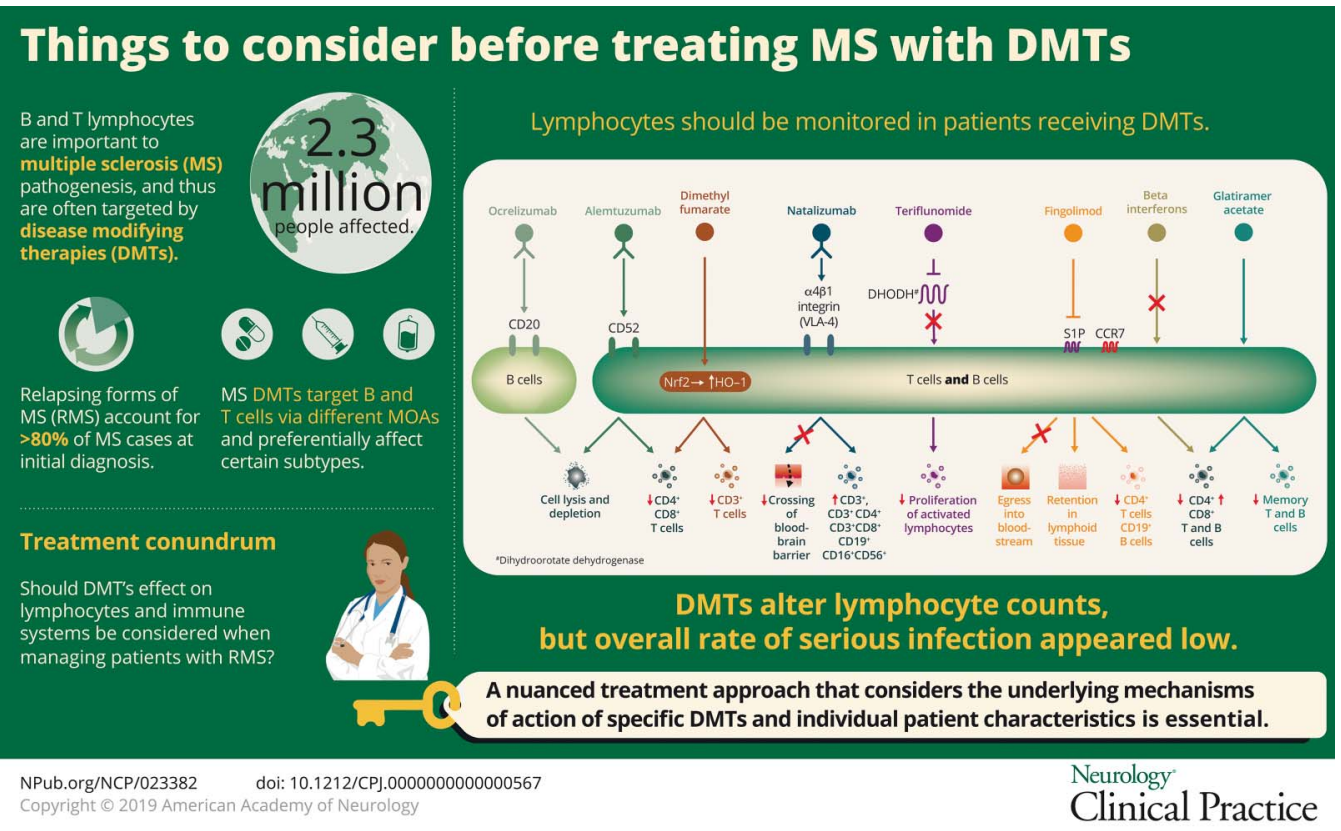




\section{Neurology ${ }^{\circ}$ Clinical Practice}

\section{Lymphopenia and DMTs for relapsing forms of MS: Considerations for the treating neurologist}

Edward J. Fox, Guy J. Buckle, Barry Singer, et al.

Neurol Clin Pract 2019;9;53-63 Published Online before print January 8, 2019

DOI 10.1212/CPJ.0000000000000567

\section{This information is current as of January 8, 2019}

\begin{abstract}
Updated Information \&
Services

References

Citations

Subspecialty Collections

Errata

Permissions \& Licensing

Reprints

including high resolution figures, can be found at: http://cp.neurology.org/content/9/1/53.full.html

This article cites 66 articles, 12 of which you can access for free at: http://cp.neurology.org/content/9/1/53.full.html\#\#ref-list-1

This article has been cited by 2 HighWire-hosted articles: http://cp.neurology.org/content/9/1/53.full.html\#\#otherarticles

This article, along with others on similar topics, appears in the following collection(s):

Multiple sclerosis

http://cp.neurology.org//cgi/collection/multiple_sclerosis

An erratum has been published regarding this article. Please see next page or:

/content/9/3/184.2.full.pdf

Information about reproducing this article in parts (figures,tables) or in its entirety can be found online at:

http://cp.neurology.org/misc/about.xhtml\#permissions

Information about ordering reprints can be found online: http://cp.neurology.org/misc/addir.xhtml\#reprintsus
\end{abstract}

Neurol Clin Pract is an official journal of the American Academy of Neurology. Published continuously since 2011, it is now a bimonthly with 6 issues per year. Copyright Copyright $\odot 2019$ The Author(s). Published by Wolters Kluwer Health, Inc. on behalf of the American Academy of Neurology.. All rights reserved. Print ISSN: 2163-0402. Online ISSN: 2163-0933.

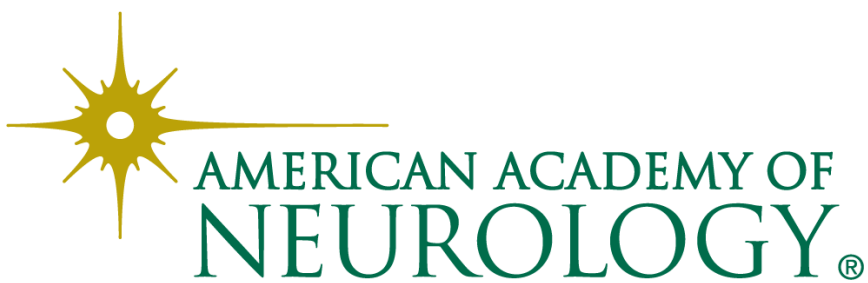


BioVision, Boston Scientific, Dr. Reddy's, electroCore, Eli Lilly, eNeura Therapeutics, GlaxoSmithKline, Merck, Pernix, Pfizer, Supernus, Teva, Trigemina, Vector, and Vedanta. He receives royalties from Wolff's Headache 7 th and 8th Edition, Oxford Press University, 2009, Wiley and Informa. Full disclosure form information provided by the authors is available with the full text of this article at Neurology.org/cp.

\section{References}

1. Chelse AB, Kurz JE, Gorman KM, et al. Remote poststroke headache in children: Characteristics and association with stroke recurrence. Neurol Clin Pract 2019;9: 194-200.
2. Lai V, Caplan L. Are some ophthalmoplegias migrainous in origin? Neurol Clin Pract 2019;9:256-262.

3. Weissman B, Joseph M, Gronseth G, Sarmiento K, Giza CC. CDC's Guideline on Pediatric Mild Traumatic Brain Injury: Recommendations for neurologists. Neurol Clin Pract 2019;9:241-249.

4. Robblee J, Kelly S. Headache: Illustrating the patient experience. Neurol Clin Pract 2019;9:271-272.

5. Goadsby P. Primary headache disorders: Five new things. Neurol Clin Pract 2019;9: 233-240.

6. Messina R, Goadsby PJ. CGRP — a target for acute therapy in migraine: clinical data. Cephalalgia 2019;39:420-427.

7. Edvinsson L, Goadsby PJ. Discovery of CGRP in relation to migraine. Cephalalgia 2019;39:331-332.

8. Turner S, Foss-Barratt A, Malmberg J, Disabato J. Minding the gap in pediatric headache care: Can a focus on quality measures improve outcomes? Neurol Clin Pract 2019;9:187-193.

\title{
CORRECTIONS
}

\section{Message from the Editors to our Reviewers}

Neurology: Clinical Practice June 2019 vol. 9 no. 3184 doi:10.1212/CPJ.0000000000000677

In the article "Message from the Editors to our Reviewers" by Corboy et al., ${ }^{1}$ first published online April 8, 2019, the penultimate sentence in Dr. John Corboy's disclosures should have read 'He is a consultant to Novartis, participating on a steering committee, and Mylan, on a legal issue.' The author regrets the error.

\section{Reference}

1. Corboy JR, Powers LB, Anderson DC, and Barbano RL. Message from the Editors to our Reviewers. Neurol Clin Pract 2019;9:90-92.

\section{Lymphopenia and DMTs for relapsing forms of MS: Considerations for the treating neurologist}

\author{
Neurology: Clinical Practice June 2019 vol. 9 no. 3184 doi:10.1212/CPJ.0000000000000676
}

In the infographic for the article "Lymphopenia and DMTs for relapsing forms of MS: Considerations for the treating neurologist" by Fox et al., first published online January 8, 2019, a red "X" should have appeared on the arrow pointing to "egress into bloodstream." This was corrected online on February 11, 2019. The authors regret the error.

\section{Reference}

1. Fox EJ, Buckle GJ, Singer B, Singh V, and Boster A. Lymphopenia and DMTs for relapsing forms of MS: Considerations for the treating neurologist. Neurol Clin Pract 2019;9:53-63. 